\title{
GARDEN PROFILE: AUCKLAND BOTANIC GARDENS
}

\author{
Jack Hobbs ${ }^{1} \&$ Rebecca Stanley ${ }^{2}$
}

\begin{abstract}
Auckland Botanic Gardens is a relatively young botanic garden that opened in 1982 and covers 64 hectares in Manurewa, South Auckland. The plant collections include both exotic and New Zealand (NZ) native plants. The native plant collections are described and illustrated. The use of native plants for environmental and ecological enhancement is also explained.
\end{abstract}

\section{HISTORY OF AUCKLAND BOTANIC GARDENS}

In 1968, the Manurewa site was purchased for a botanic garden by the now defunct Auckland Regional Authority (ARA). Proposals for a garden had been discussed in preceding years, indeed as early as 1926. The first masterplan for a garden was prepared in consultation with a community scientific advisory committee and adopted by the ARA in 1972. The following year, work began with the establishment of a nursery. Auckland Botanic Gardens (ABG) were officially opened on 23 February 1982 (Murdoch, 2010). Visitor numbers in the first year were 98,000. The garden is largely funded by Auckland Council covering core operations, capital renewals and most developments. The Friends of Auckland Botanic Gardens provide funding and support for events, artworks, research, scholarships and some other projects and activities. ABG is rapidly becoming one of Auckland's most popular visitor destinations. Annual visitation for 2005 was 460,000. This more than doubled by 2010, reaching 965,000, and exceeding 1 million in 2014 .

Two particularly significant milestones occurred in 2005. The Potter Children's Garden was formally opened by HRH The Prince of Wales on 10 March 2005. This area of the garden aims to attract family groups to $\mathrm{ABG}$ and was the first collection to directly address visitor experience (Fig. 1). This has proved to be a great success and it remains a popular attraction for children and their families. It also provides a location for the delivery of environmental education programmes. The 'Huakaiwaka' visitor centre was opened by the Prime Minister the Rt Hon. Helen Clark on 9 April 2005 (Fig. 2). Most visitors arrive through this facility and it has become an attraction in its own right. Fig. 3 shows a map of the garden and the location of these areas.

1. Jack Hobbs is Manager of Auckland Botanic Gardens.

Address: Auckland Botanic Gardens, 102 Hill Road, Manurewa 2105, Auckland, New Zealand.

Email: Jack.Hobbs@aucklandcouncil.govt.nz

2. Rebecca Stanley is Curator of Auckland Botanic Gardens. 


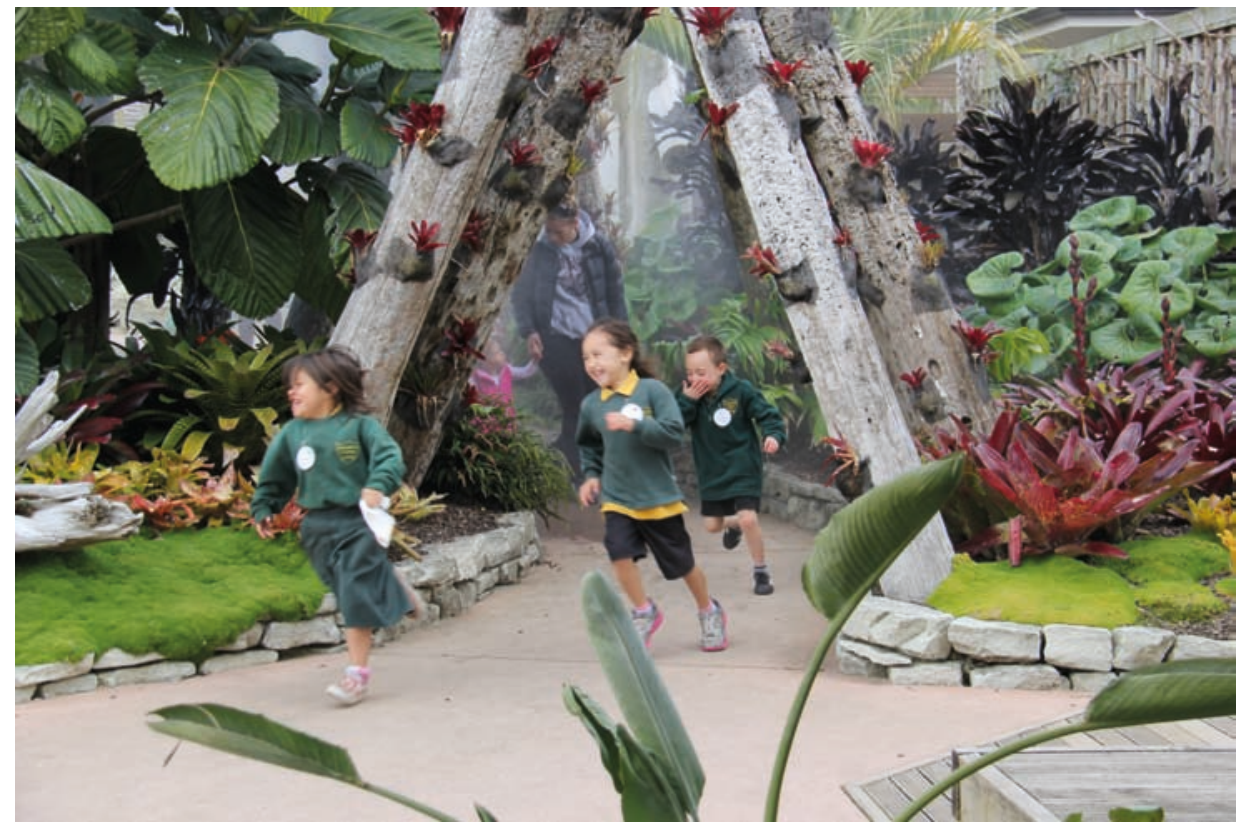

Fig. 1 Children enjoying the tropical section of the Potter Children's Garden. Photo: Jack Hobbs.

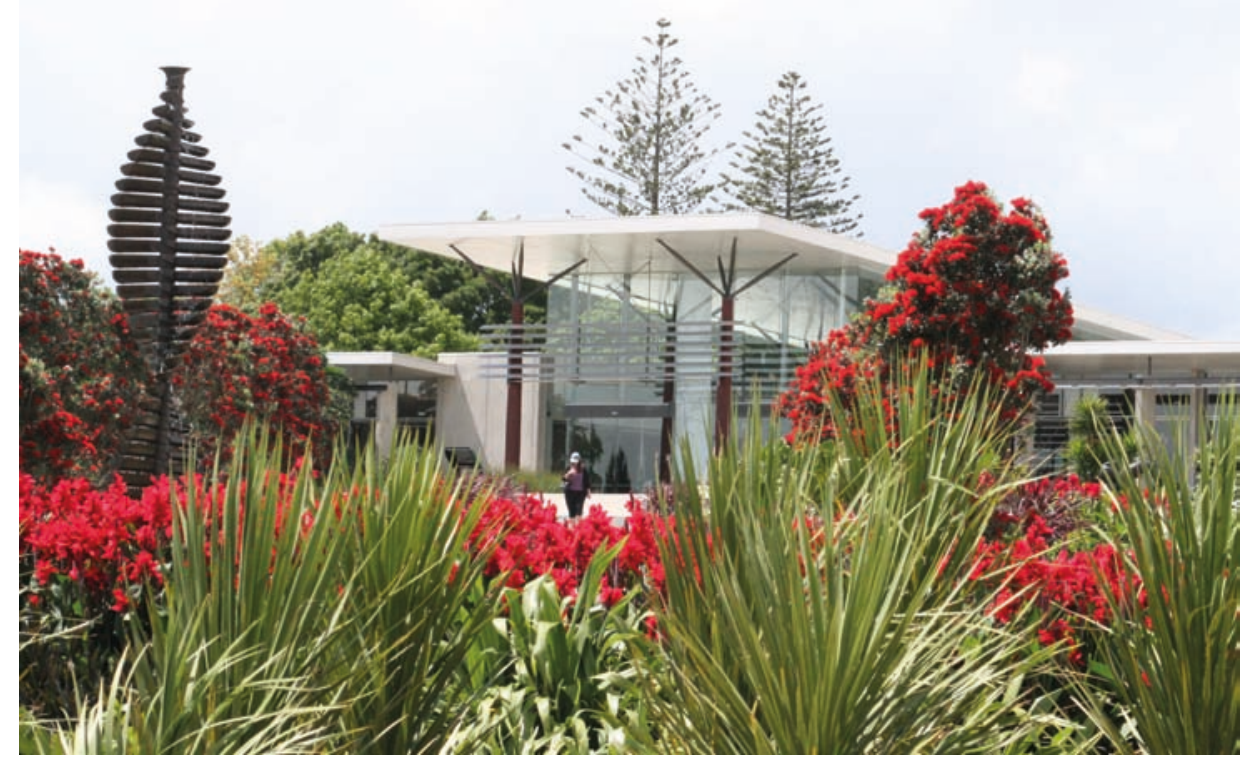

Fig. 2 ABG visitor centre at Huakaiwaka with Metrosideros excelsa in flower. Photo: Jack Hobbs. 


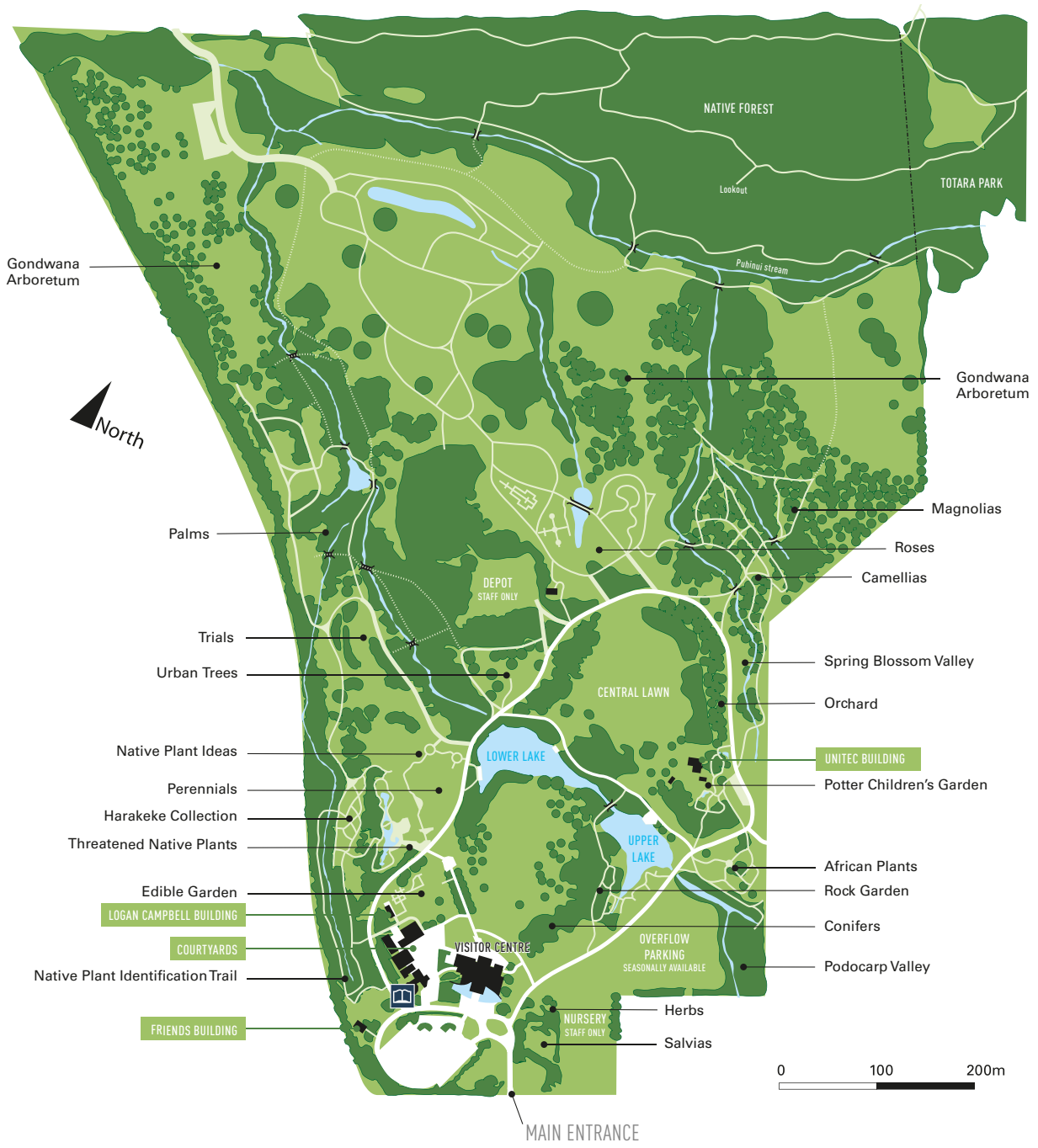

Fig. 3 Map of Auckland Botanic Garden. Map produced by Jan Ramp.

\section{THE LOCATION OF AUCKLAND BOTANIC GARDENS}

Auckland's Maori name is Tāmaki Makaurau. It is the most populous city in New Zealand, with more than 1,500,000 residents, and it has the largest Polynesian population of any city in the world.

Auckland is located on latitude $36.5^{\circ}$ south. This is similar to Malaga in southern Spain and Monterey, California in the northern hemisphere, but the moderating effects of the surrounding oceans ensure that Auckland is cooler than these places. The climate is warm and humid during summer and cooler and wetter during winter. The average 
maximum daytime temperature is $23.7^{\circ} \mathrm{C}$ in February and $14.5^{\circ} \mathrm{C}$ in July. Summer temperatures seldom exceed $30^{\circ} \mathrm{C}$, and winters are typically mild with a few light frosts. Average annual rainfall is around $1,240 \mathrm{~mm}$, with relatively high levels of rainfall generally occurring throughout the year, although heaviest rainfall occurs from May to August.

\section{THE MANAGEMENT OF AUCKLAND BOTANIC GARDENS}

Four strategic documents guide the management of ABG - a Management Plan (2001), a Master Plan (2010), a Marketing Plan (2013) and Plant Collections Guidelines (in preparation, 2014).

The Management Plan sets out goals, policies and objectives for the core business of the gardens relating to plant collections, recreation activities and facilities, education, conservation and environmental values, science and fostering relationships. The Master Plan guides the long-term future development of ABG. An important purpose is to harmoniously unite the various and complex components of $\mathrm{ABG}$ in a manner that optimises visitor enjoyment, way finding and understanding of key messages. The Marketing Plan provides direction for visitor services and engagement in order "to engage people with plants and make them more important in their lives", as encapsulated in the ABG strapline 'Where Ideas Grow'.

The Plant Collections Guidelines provide a framework for the care, management and development of the ABG plant collections and amenity plantings and the botanic services that support them. More than 40,000 plants are currently recorded in the collections. These records are managed with the $B G-B A S E$ database system (Walter \& O’Neal, 1985-2010).

THE PLANT COLLECTIONS

The plant collections make the most important contribution to recreational enjoyment of $\mathrm{ABG}$; they also underpin all the education programmes and provide the basis of the conservation work and research that is carried out.

Since 2000, ABG has undertaken a pesticide minimisation programme. All plant management practices aim to maximise the health of plants, gardens, natural areas and waterways and enhance the diverse abundance of life that coexists on site. This includes fostering an abundant balanced microbial ecosystem. Contributing practices include composting and regular applications of organic mulch which help to sustain soil life and plant health. The pesticide minimisation programme is supported by an extensive trial programme that identifies and promotes high-performing plants that remain healthy without pesticide intervention. Trials also inform our plant selection recommendations and other advisory services.

In recent years, particular focus has been given to the role that plants play in environmental enhancement, particularly stormwater management utilising Low Impact Design 
(LID) principles. A series of integrated systems protect and enhance our waterways through treating stormwater before it enters the streams and lakes.

\section{OVERVIEW OF THE NEW ZEALAND FLORA}

Of the (approximately) 2,026 plants indigenous to New Zealand 82 per cent are endemic (Breitwieser et al., 2012). This is thought to be the result of many factors, including New Zealand's geological isolation from other major land masses for 60-80 million years, chance oceanic dispersal events, geological activity, glaciation, sea level rise (and fall) and biotic interactions such as the absence of herbivorous mammals.

Coupled with high endemism are the numerous unusual botanical features such as a high proportion of plants with separate male and female individuals (dioecy), many plants with different adult and juvenile growth forms, proportionally less brightly coloured flowers than other floras, high variations in seed output (mast seeding) and divaricating plants - those with right-angled branching creating springy impenetrable life forms - which possibly evolved as a defence mechanism to browsing by the extinct ratite bird, the moa.

\section{NATIVE PLANT BREEDING}

ABG has conducted extensive native plant breeding programmes. Most of this plant breeding activity took place between 1982 and the mid-1990s when it was curtailed largely due to a lack of resources. The programme focused mainly on producing new cultivars of Hebe spp. (Plantaginaceae) and Leptospermum scoparium (Myrtaceae). One of the primary objectives was to produce hebe cultivars which were resistant to diseases that commonly afflict these popular garden subjects in Auckland's warm humid climate. Most cultivars that have been generated from this programme include 'Wiri' in the cultivar name. Popular cultivars include the following:

Hebe 'Wiri Mist' is a compact spreading shrub with abundant white flowers in late spring (Fig. 4). It is widely used in NZ as a garden subject and can be clipped as a low formal hedge.

$H$. 'Wiri Vision' is a large shrub to around $1.2 \mathrm{~m}$ with reddish-purple flowers which are most prolific during summer. It thrives near the coast but does not tolerate heavy frosts.

Leptospermum scoparium 'Wiri Sandra' produces a profusion of single pink flowers from winter until late spring (Fig. 5).

$L$. 'Wiri Kerry' is a compact shrub to around $80 \mathrm{~cm}$ with semi-double rose-red flowers (Fig. 6). 


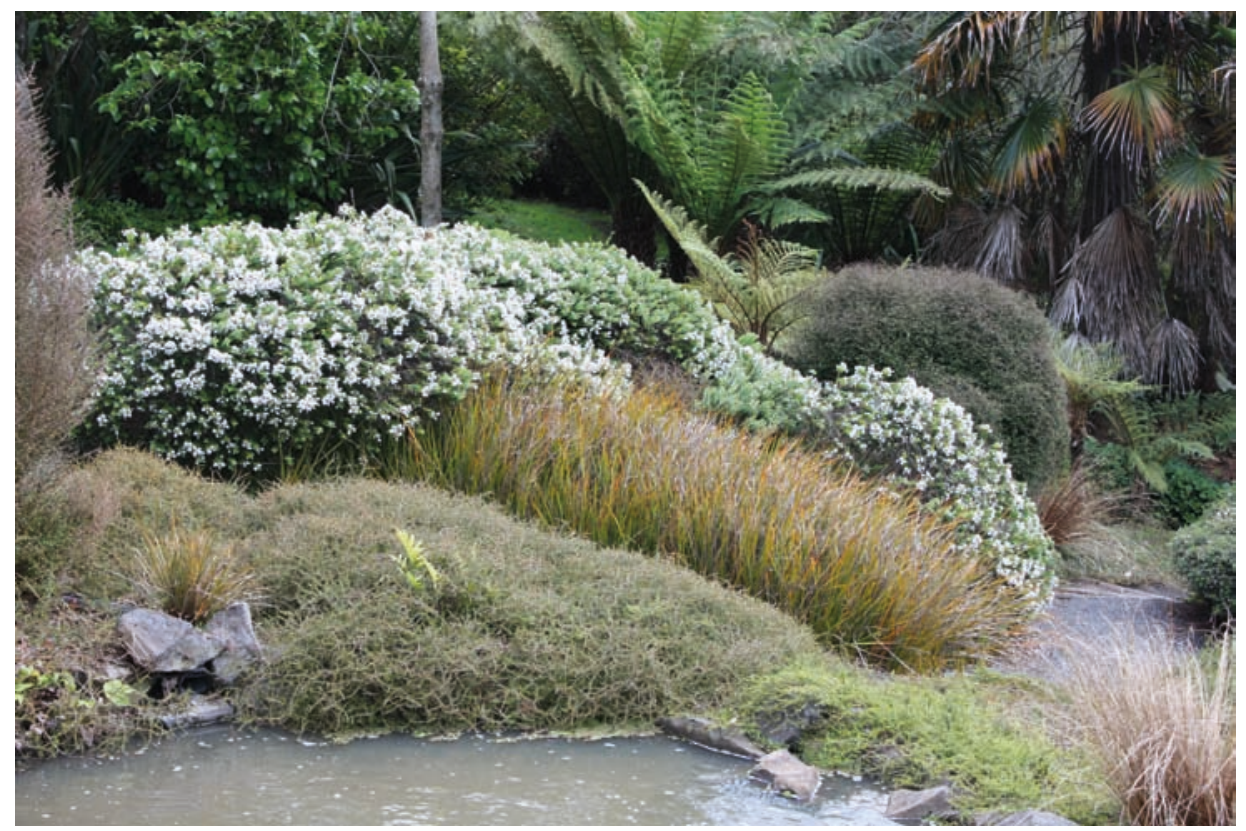

Fig. 4 One of the most popular ABG cultivars Hebe 'Wiri Mist' at Ayrlies Garden, a private garden east of Auckland, with Coprosma acerosa and Libertia peregrinans in front. Photo: Jack Hobbs.

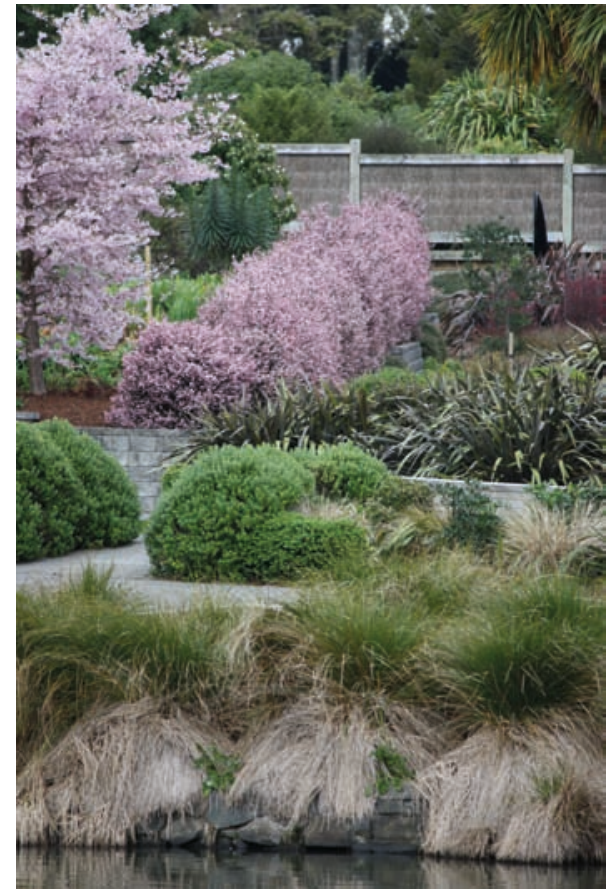

Fig. 5 Leptospermum 'Wiri Sandra' used as a hedge in the Native Plant Ideas Garden. Photo: Jack Hobbs.

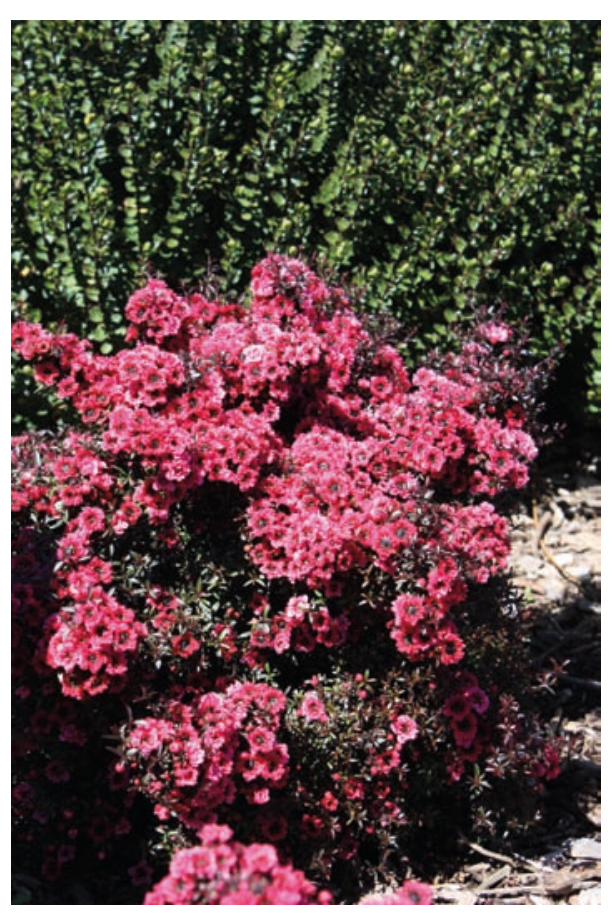

Fig. 6 Popular compact ABG cultivar

Leptospermum 'Wiri Kerry'. Photo: Jack Hobbs. 


\section{NATIVE PLANT COLLECTIONS}

ABG holds four distinct native plant collections which are described in more detail below. Native plants are also used throughout ABG, and they feature extensively in a range of stormwater treatment devices. Significant collections of NZ native trees held at ABG include the following:

Pohutukawa (Metrosideros excelsa Myrtaceae) is a large tree of coastal northern NZ producing spectacular displays of typically red flowers, although other colours also occur. It flowers mainly in December and is often called the NZ Christmas tree. ABG holds a comprehensive collection of cultivars that have been selected primarily for their superior flowering qualities but also for their adult form (Figs $7 \& 8$ ).

Kowhai (Sophora spp. Leguminosae) holds a significant collection of cultivars of this iconic and variable native tree that occurs naturally throughout the country (Fig. 9).

Totara (Podocarpus totara Podocarpaceae) is the predominant naturally occurring tree at ABG. These are present in large stands and as individual specimens and they provide a significant structural element and sense of maturity in the landscape.

\section{Native Plant Identification Trail}

The Native Plant Identification Trail was one of the first collections in the gardens to be established at ABG with initial plantings taking place in 1976. This collection highlights the key identification characteristics of a wide selection of NZ native plants that are

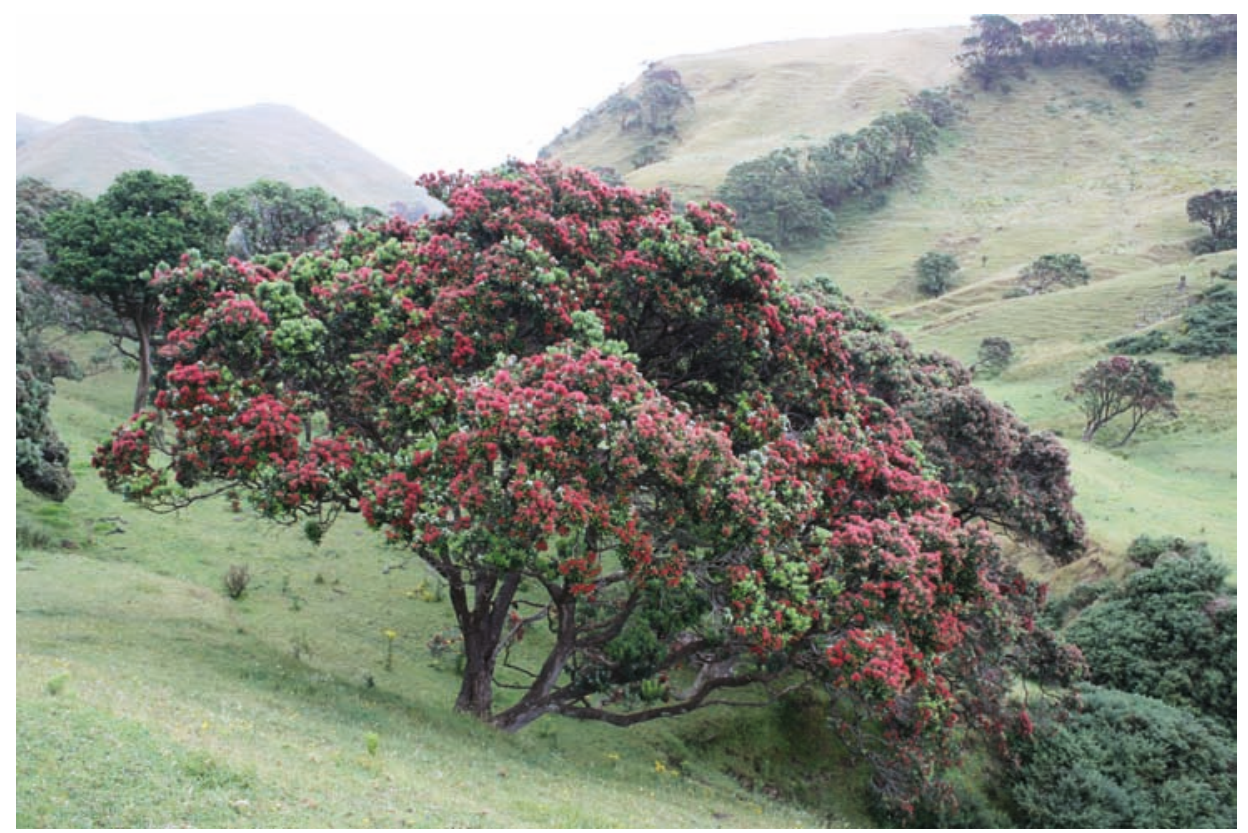

Fig. 7 Metrosideros excelsa remnant trees on farmland, Awhitu, south of Auckland. Photo: Jack Hobbs. 


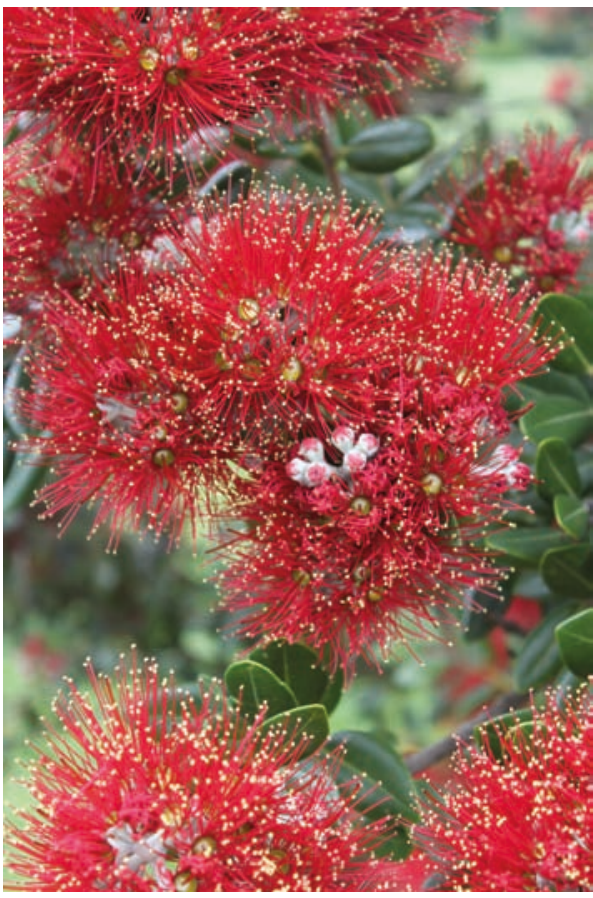

Fig. 8 Metrosideros excelsa, superior flowering form in ABG collection. Photo: Jack Hobbs.

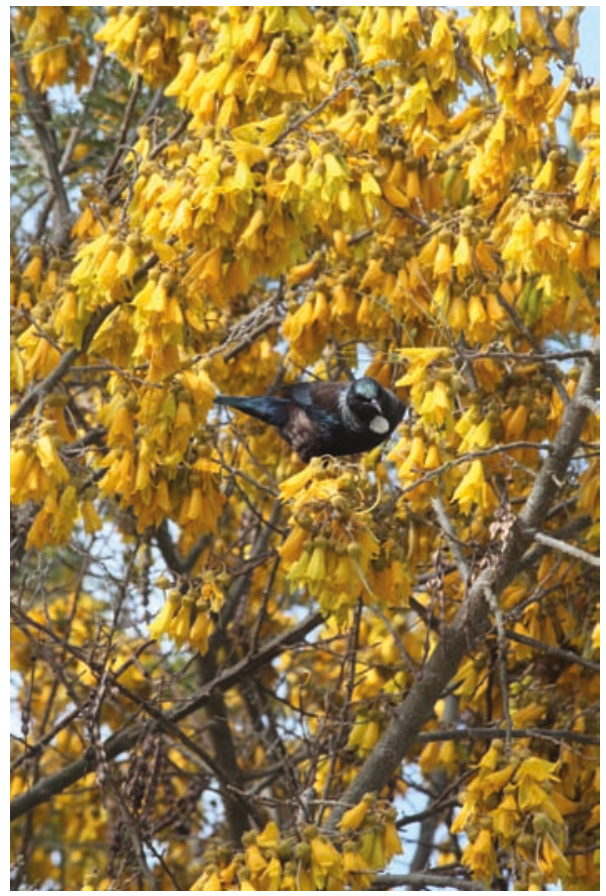

Fig. 9 Tui feeding on Sophora fulvida (kowhai). Photo: Jack Hobbs.

commonly encountered in northern forests. This enables school groups and visitors to view and readily identify a range of native plants by highlighting their most readily observable characteristics. The primary objective of the collection is to enable visitors to identify a wide range of more commonly encountered native plant species. Interpretation provides information on the diversity and adaptive features of the plants, and on the traditional Maori uses of native plants.

The collection contains a wide range of NZ native trees, shrubs, perennials and climbers. Interesting and unusual forms of NZ natives such as divaricating plants and those with different juvenile and adult foliage are also displayed. Most of the plants are wild collected of known origin from Auckland and Northland ecological regions including offshore islands. The collection data is all recorded on $B G-B A S E^{\mathrm{TM}}$.

\section{Native Plant Ideas}

The Native Plant Ideas garden was developed in 2004 and features species and cultivars selected for proven performance in Auckland conditions. The primary objective of this garden is to inspire visitors to use native plants of exceptional performance in effective and innovative ways. This includes topiary and hedging with emphasis on planting combinations that highlight their texture, form and colour (Fig. 10). The plants are 
attractively combined in creatively designed gardens to stimulate visitor interest and uptake of ideas. The garden also conveys ideas for managing plants in a manner that controls their size and enhances their appearance.

The plants are grouped in the following design themes:

- Subtropical - features bold foliage and the lushness of many New Zealand plants

- Coastal - plants that tolerate salt-laden winds near the beach

- Residential Courtyard - innovative ideas for planting where space is limited

- Collector's Corner - interesting and unusual plants

- Textures - diverse textures of foliage and form in effective combinations

- Colour Border - graduated foliage colours from pink shades at one end to yellows at the other with groupings of other shades in between

- Formal - creative shapes and symmetry

\section{Threatened Native Plant Garden}

In this collection threatened native plants are grown in replica natural habitats which are representative of those in which they typically occur. The aim is to increase public awareness of threatened plant species, the reasons for their decline and opportunities for their recovery. It also assists with the identification of threatened plants, and stock is maintained as an ex situ conservation collection for reintroduction and seed bank programmes. It is also

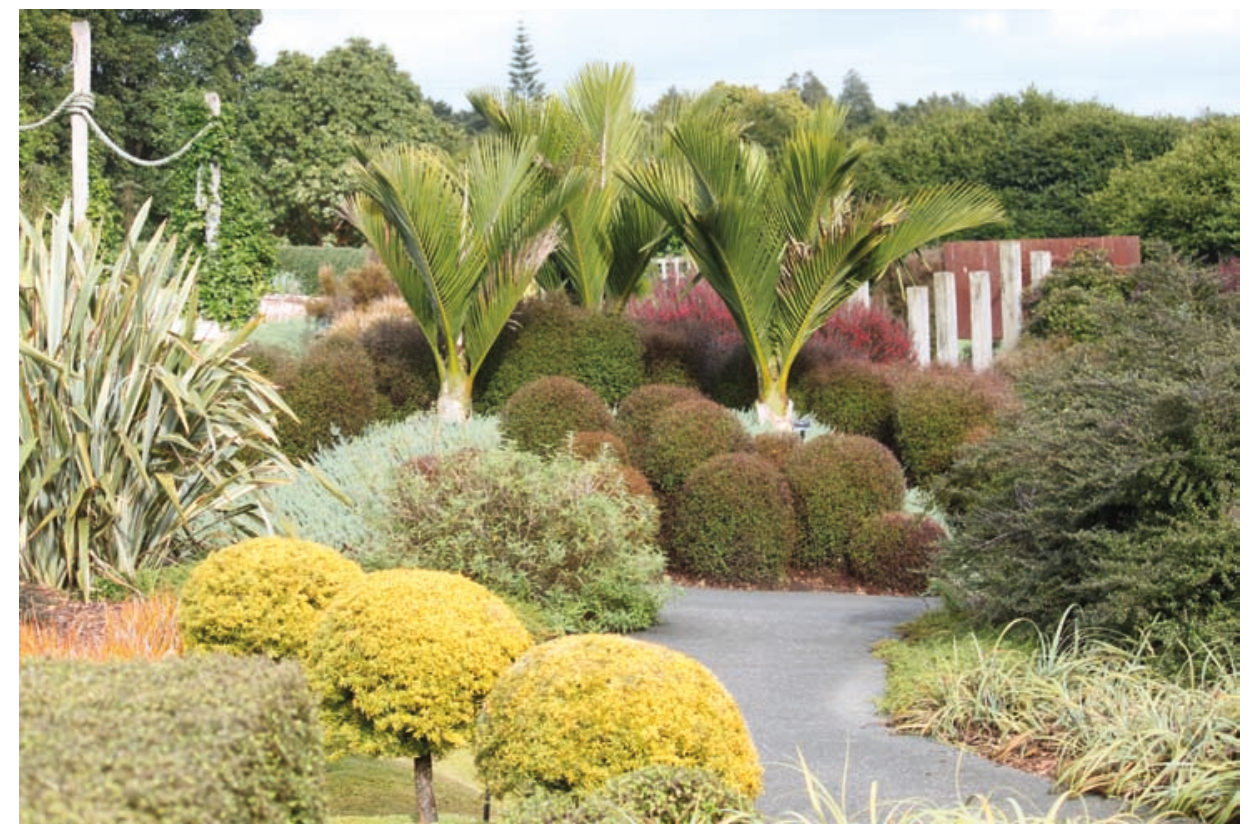

Fig. 10 Native Plant Ideas Garden featuring Rhopalostylis sapida, with clipped Muehlenbeckia astonii beneath and clipped Podocarpus totara 'Aurea' in the foreground. Photo: Jack Hobbs. 
hoped that by displaying these plants they are promoted for wider use in home gardens and amenity plantings. The garden was opened in 2001 by Prime Minister the Rt Hon. Helen Clark. The habitats recreated in this area include: inland scrub forest, streamside, swamp, gumland, coastal scrub forest, offshore island boulder beach, lava field, coastal rocky bluff and coastal wetland, salt marsh, shell bank, forest dune and sand dune.

The threatened native plants are predominantly from northern New Zealand, including offshore islands. Usually just one threatened species is highlighted per habitat with associated interpretation conveying its plight and other information. The threatened plants are planted along with a range of non-threatened plants that typically occur in the same habitats.

There are two species that have been the focus of successful ABG plant recovery programmes, both of which feature in the Threatened Native Plant Garden.

Shore spurge (Euphorbia glauca Euphorbiaceae) - since 1999, Auckland Botanic Gardens have worked with the NZ Department of Conservation to save the single remaining plant of shore spurge (Fig. 11) on Brown's Island/Motukorea in the Hauraki Gulf. This plant is one of Auckland's most threatened plants suffering a dramatic decline over the last 100 years with its range contracting from eleven sites to just two. On Brown's Island only one plant remained, high on a coastal cliff. Cuttings were taken and grown at $\mathrm{ABG}$ both as an insurance population and also to bulk up plants for returning to the island, which occurred in 2003 and 2004.

Kakabeak (Clianthus puniceus Leguminosae), a beautiful shrub admired by gardeners worldwide, grows on only one island in the Kaipara Harbour near Auckland. In the late 1990s seed was collected from this island and grown at $\mathrm{ABG}$ in a seed orchard, providing a conservation resource for returning plants to the wild. No other Clianthus species are grown at the gardens to ensure the material does not outcross (Fig. 12).

\section{Harakeke Collection}

This is a comprehensive collection of all known Phormium (Hemerocallidaceae) cultivars traditionally used by Maori for weaving and extracting fibre (muka). Support plantings include other weaving plants and dye plants used by Maori. The collection commenced in 1989 and has increased incrementally since that time.

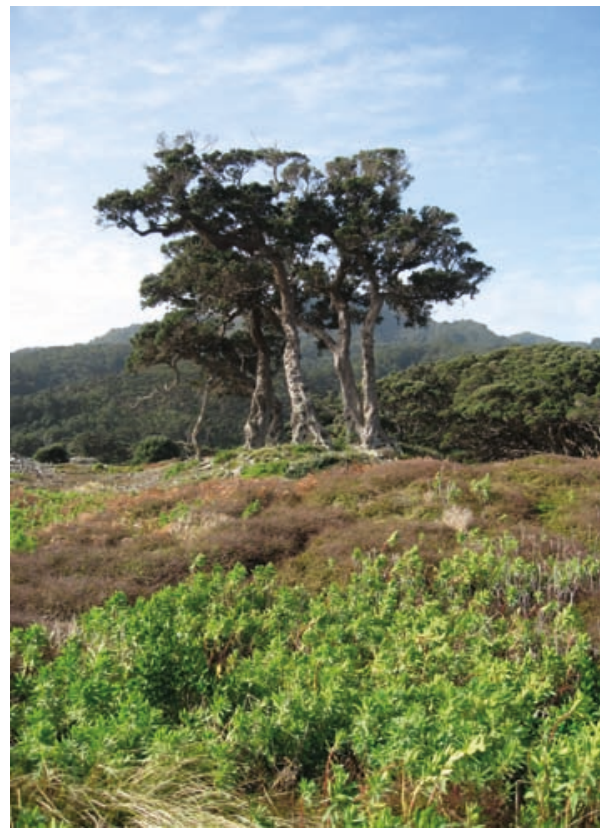

Fig. 11 Euphorbia glauca growing wild on Little Barrier Island. The tree behind is a pohutukawa. Photo: Rebecca Stanley. 
The main objectives of this collection are to grow and display traditional Maori weaving cultivars of harakeke to create awareness of their economic and cultural importance to Maori and subsequently to European settlers (Fig. 13). Traditional maintenance techniques and protocols are practised, and educational opportunities provided that highlight traditional harvesting techniques, weaving practices and fibre extraction. Plant material is provided to others wishing to use traditional harakeke in weaving, and for education and research.

\section{NEW ZEALAND NATIVE PLANTS IN STORMWATER TREATMENT SYSTEMS}

In recent years NZ has placed increasing importance on improving the health of waterways. Stormwater can have a major impact on waterway health through depositing contaminants and sediment and erosion of stream banks. Since 2007, ABG has applied a stormwater management progamme based on LID principles to protect and enhance the health of our waterways as well as increasing habitat for native birds, insects and reptiles. ABG is now a showcase for stormwater treatment systems in the Auckland region and has installed living (green) roofs, vegetated swales, rain gardens, riparian

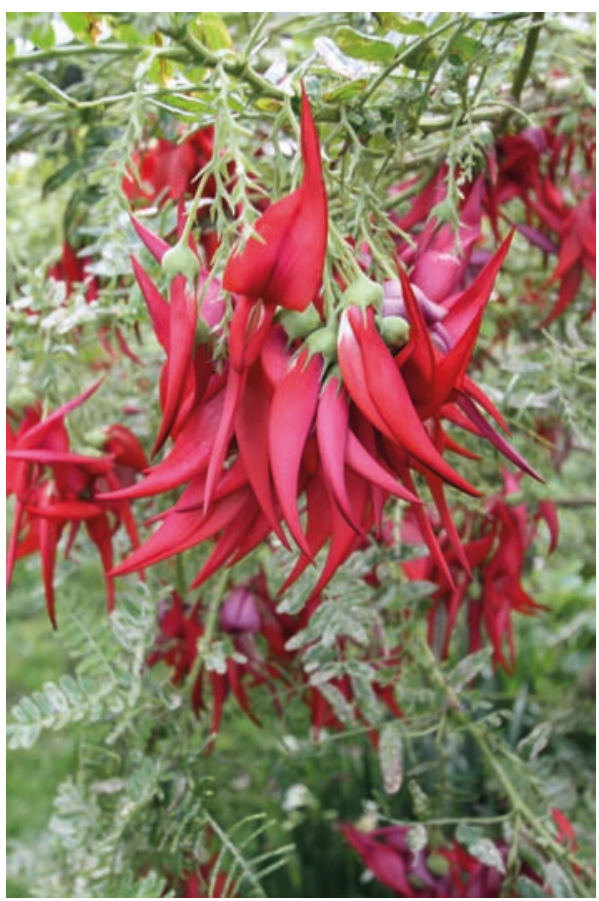

Fig. 12 Clianthus puniceus (kakabeak) growing at ABG as part of the ex situ conservation collection. Photo: Jack Hobbs.

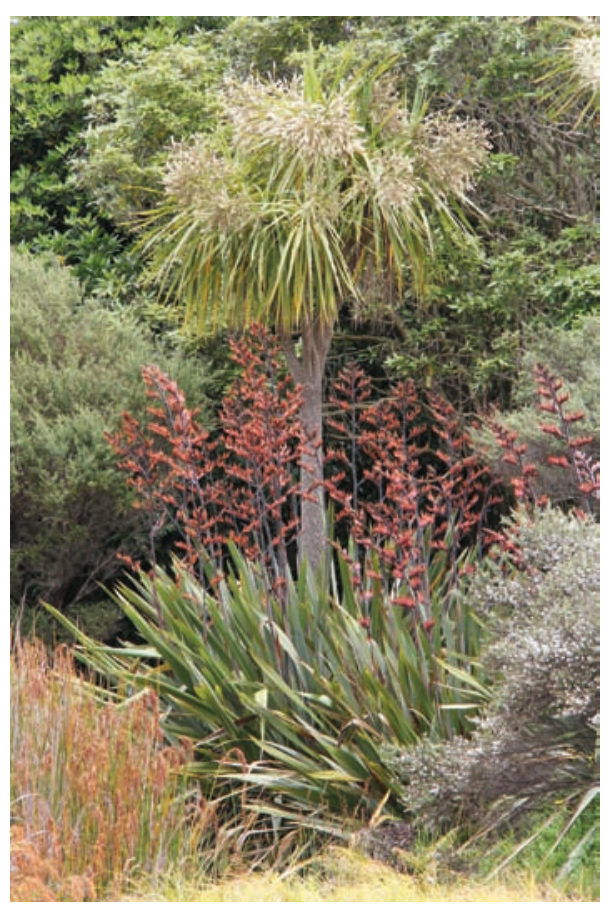

Fig. 13 Phormium tenax (harakeke) beneath Cordyline australis at ABG. Photo: Jack Hobbs. 
plantings, stormwater planter boxes, infiltration trenches, a stormwater tree pit and stormwater wetlands.

The main focus for $\mathrm{ABG}$ is the selection and subsequent evaluation of native plant species for suitability in stormwater treatment systems. Observation of plants in their wild habitats has largely informed the selection of plants for these systems. Species naturally adapted to dry conditions have generally proved more successful in such applications than those naturally found in constantly waterlogged situations such as wetlands. Exceptions are the base of vegetated swales and stormwater wetlands. The following two native species have demonstrated exceptional performance in contrasting situations:

The reed-like oioi (Apodasmia similis Restionaceae) has proven to be the most effective of all species yet trialled in situations that experience period flooding such as vegetated swales (Fig. 14). The extensive surface root system resists erosion, and the reed-like texture effectively slows stormwater speed without causing blockages. Used appropriately it significantly reduces loadings of sediment, nutrients and heavy metals.

Austrostipa stipoides Gramineae is extremely drought-tolerant and is proving to be the most successful species yet trialled on our NZ native living roof (Fig. 15). This NZ native coastal grass has upright smooth rolled leaves to $80 \mathrm{~cm}$ and tolerates prolonged aridity, heat and strong winds. It has a shallow, dense root system adapted to survival with minimal root run on the sheer coastal cliffs where it naturally occurs.

Other native species that have established well include Libertia peregrinans (Iridiaceae), Arthropodium cirratum (Laxmanniaceae) (small cultivars), Coprosma acerosa (Rubiaceae), Pimelea prostrata (Thymelaeaceae), Disphyma australe (Aizoaceae) (NZ ice plant) and Xeronema callistemon (Xeronemataceae) (poor knight's lily).

A key educational objective is to raise community awareness of waterway health issues and the role plants can play in resolving these. This is achieved through interpretation that highlights the environmental benefits that accrue when a comprehensive range of LID devices are connected in an integrated manner. Target audiences are public and private agencies that may utilise such systems as well as the general public and schoolchildren. The ABG environmental education programme includes 'S.O.S' (save our streams) which focuses on the ABG streams and waterways. It is part of the curriculum-based 'Learning Through Experience' programme delivered to more than 8,000 schoolchildren annually. A printed guide entitled 'Sustainable Water Trail' enables visitors to better understand the function and connectedness of the various devices. Each device has interpretive signage.

\section{SUMMARY}

Although still a relatively young botanic garden, $A B G$ is making significant progress in developing and refining its plant collections and the services it provides to the community. It is now a major destination and a key contributor to horticulture, education and conservation in the Auckland region. The recent completion of strategic planning 


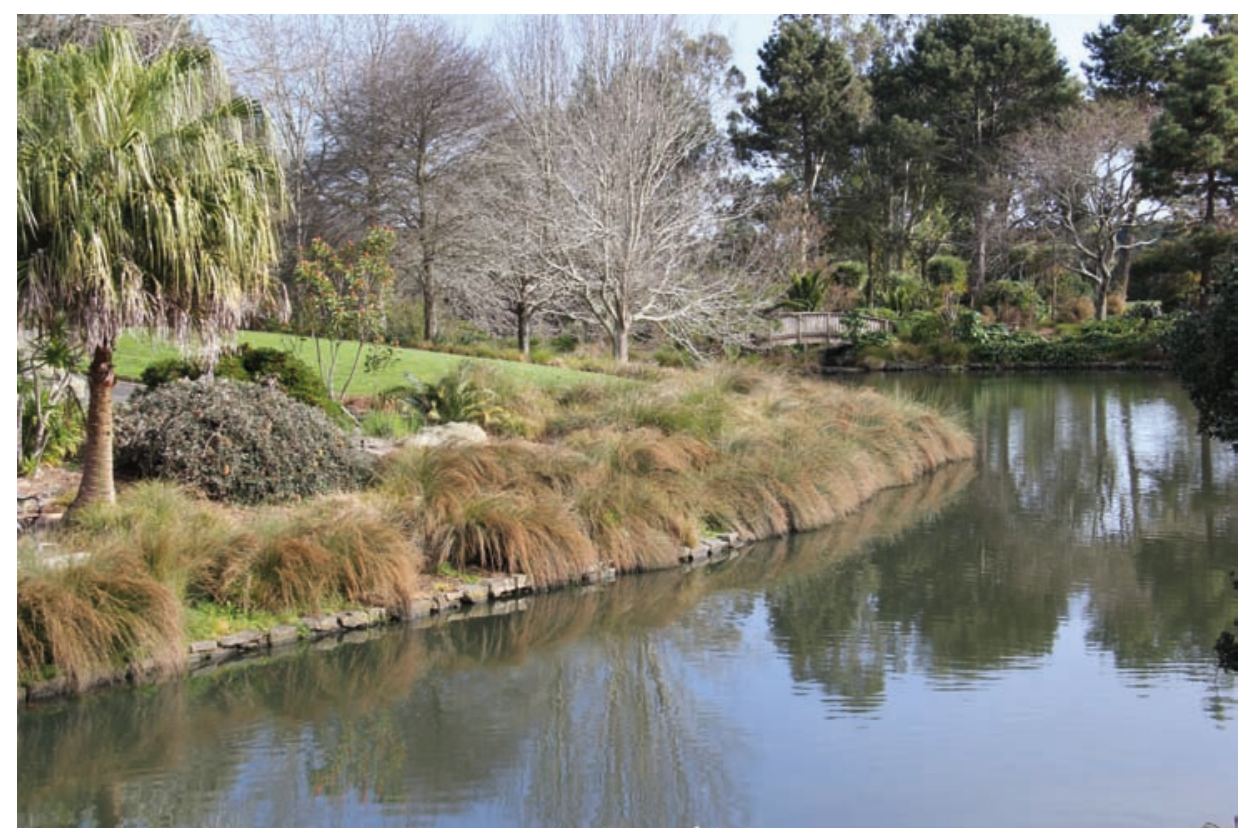

Fig. 14 Apodasmia similis in riparian planting at ABG. Photo: Jack Hobbs.

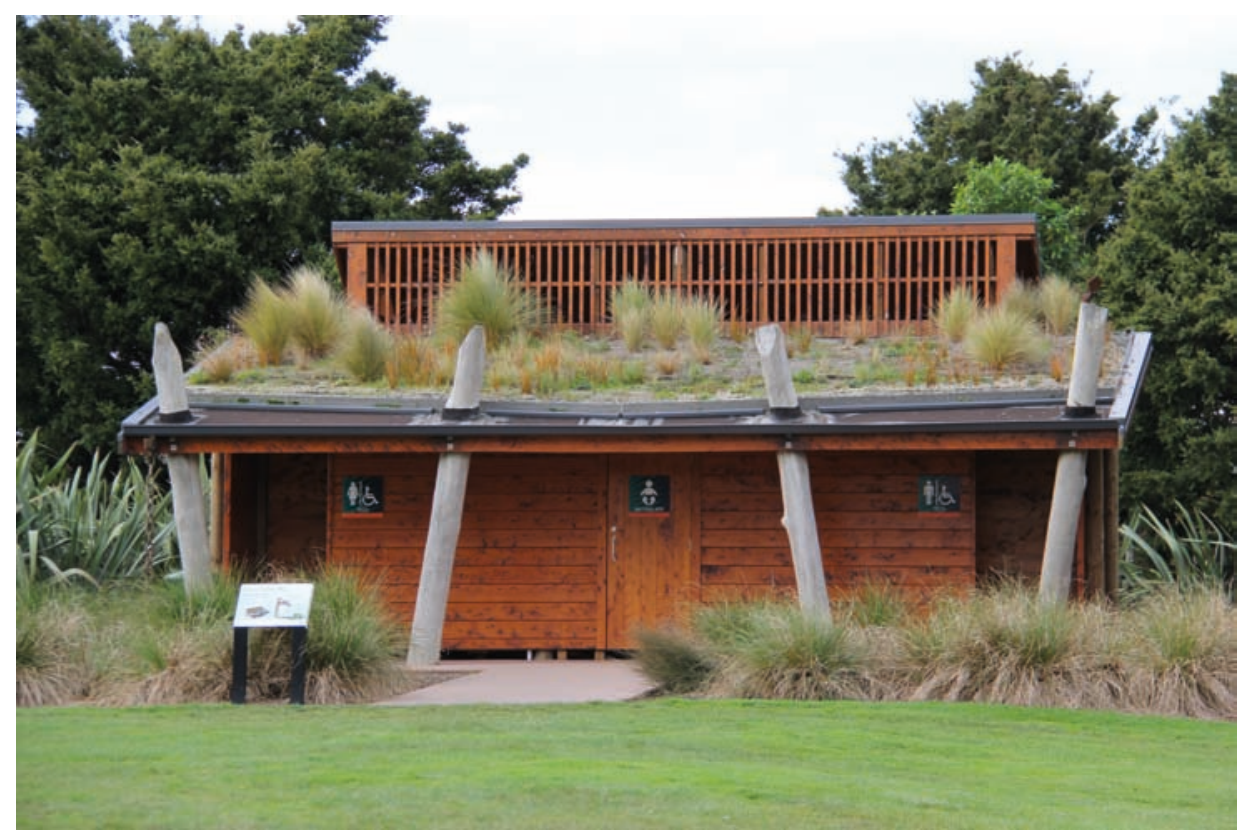

Fig. 15 Austrostipa stipoides and other native plants on the green roof at ABG. Photo: Jack Hobbs. 
documents and rapidly increasing community support bode well for the future. It is essential for us to remain relevant to our community and in doing so increase their understanding and appreciation of plants.

\section{REFERENCES}

AUCKLAND COUNCIL (2001). Auckland Botanic Gardens Management Plan. Auckland Council, Auckland.

AUCKLAND COUNCIL (2010). Auckland Botanic Gardens Master Plan. Auckland Council, Auckland.

AUCKLAND COUNCIL (2013). Auckland Botanic Gardens Marketing Plan. Auckland Council, Auckland.

AUCKLAND COUNCIL (2014, in prep.). Plant Collections Guidelines. Auckland Council, Auckland.

BREITWIESER, I., BROWNSEY, P.J., GARNOCK-JONES, P., PERRIE, L.R. \& WILTON, A.D. (2012). Phylum Tracheophyta: vascular plants. In: GORDON, D.P. (ed.), New Zealand Inventory of Biodiversity, Volume 3. Kingdoms Bacteria, Protozoa, Chromista, Plantae, Fungi. Canterbury University Press, Christchurch, pp. 411-459.

MURDOCH, G. (2010). Dreamers of the Day. A History of Auckland's Regional Parks. Auckland Regional Council, Auckland.

WALTER, K.S. \& O’NEAL, M.J. (1985-2010). BG-BASE [Collection Management Software] BG-BASE inc. BG-BASE (UK) Ltd. Available at: www.bg-base.com (Accessed: 1 April 2013). 